\title{
Fibroblast Growth Factor Receptor Family Gene
}

National Cancer Institute

\section{Source}

National Cancer Institute. Fibroblast Growth Factor Receptor Family Gene. NCI

Thesaurus. Code C19930.

Fibroblast Growth Factor Receptor Family Genes encode Fibroblast Growth Factor Receptor Family proteins, cell surface receptors that react with (basic or acidic) fibroblast growth factors and frequently possess tyrosine kinase activity to elicit specific cellular responses to these growth factors. $(\mathrm{NCl})$ 